\title{
Assessing the Impact of Wastewater Effluent Diversion on Water Quality
}

\author{
Jolanta Dąbrowska ${ }^{1 *}$, Aleksandra Bawiec ${ }^{1}$, Katarzyna Pawęska ${ }^{1}$, \\ Joanna Kamińska ${ }^{2}$, Radosław Stodolak ${ }^{1}$ \\ ${ }^{1}$ Institute of Environmental Engineering, Wrocław University of Environmental and Life Sciences, \\ 24 Grunwaldzki Sq., 50-363 Wrocław, Poland \\ ${ }^{2}$ Department of Mathematics, Wrocław University of Environmental and Life Sciences, \\ 53 Grunwaldzka St., 50-357 Wrocław, Poland
}

Received: 16 May 2016

Accepted: 18 August 2016

\begin{abstract}
The aim of this study was to determine the change of water quality in the Trzemna River after modernisation of the wastewater treatment plant (WWTP) in Gołuchów and wastewater effluent diversion (WED) to the Prosna River in 2008. Data was acquired from the State Environmental Monitoring database for the period before and after changing the location of discharge from the treatment plant. The before-after (BA) and before-after-control-impact (BACI) analyses were used to determine the effectiveness of applied solutions. The BA study covered 12 physicochemical parameters and showed improvement of water quality in terms of phosphorous compounds, EC, ammonium nitrogen, TKN, TN, and $\mathrm{BOD}_{5}$. Lack of statistically significant differences for nitrates, $\mathrm{pH}$, and TOC were noted. The BACI analysis was only applicable for six physicochemical parameters, and statistically significant differences were shown for TN, TKN, ammonium nitrogen, and TP. There were no differences in the case of nitrates and DO. After wastewater effluent diversion, a high concentration of nitrates in Trzemna water was still observed, with a statistically confirmed increasing trend. This is an effect of the negative impact of agricultural diffuse pollution. Modernisation of a WWTP and wastewater effluent diversion positively affected the quality of Trzemna water. The BA and BACI analyses in relation to statistical tests applied in hydrology can be successfully used to evaluate the impact of changes in the environment on water quality. In the case of BA design it was possible to analyse 12 parameters, whereas in BACI analysis it was only half of them. However, this method is recognised as more reliable and eliminates the impact of natural temporary variations.
\end{abstract}

Keywords: eutrophication, wastewater effluents, wastewater treatment plant, surface water quality, impact assessment

*e-mail: jolanta.dabrowska@upwr.edu.pl 


\section{Introduction}

Municipal wastewater effluents contain many toxic substances that degrade aquatic environments, first and foremost nutrients as well as pharmaceuticals, hormones, pathogens, and chlorides. Untreated or insufficiently treated wastewater has been the source of surface water pollution for many years on all inhabited continents, and nutrients included in them affect intensification of rivers, reservoirs, and the sea's eutrophication process [1-7]. In Europe, the Water Framework Directive (WFD) and the necessity to achieve good quality water by the EU states has necessitated modernisation of many wastewater treatment plants (WWTPs) with insufficient technology and construction of modern efficient WWTPs. These actions will significantly contribute to the recovery of water bodies. However, even effluents from modern WWTPs may cause a hazard if the receiving watercourse is small in relation to the amount of effluents $[3,5,8-9]$.

The impact of human operations on water resource quality and quantity engages scientists for over 100 years, but quantitative evaluation is frequently inconvenient [5, 10-12].

Comparative methods are used to evaluate the positive or negative impacts by humans on the environment. Green [13] has presented a few types of such methods. Since the 1970s they were used mostly to evaluate the degree of environmental degradation by humans. Today, they are also used to analyse positive changes in the environment related to limitation of emissions, restoration of water bodies, or integrated catchment management [9, 1416]. Scientific literature presents many methods aimed at the limitation of pollutant discharge into freshwater and marine receiving environments; however, only a few studies have related to evaluating the effectiveness of analysed methods [14], which is why studies on developing methods concerning river restoration are necessary [16].

The prevention of eutrophication processes should be based first and foremost on understanding nutrient migration and transfer in a catchment and then on sustainable water management to local, regional, and cross-border scales [4].

Problems related to determining the impact of operations undertaken in order to improve water quality are frequent in small agricultural catchments, where water quality monitoring is not regular and performed at a small number of locations. Most frequently these are ungauged catchments and under such circumstances one can only estimate, not calculate, the pollution load [17]. The approaches to water quality data must be different than in environmental studies based on the monitoring of animal or plant populations. This data often does not meet the parametric test assumptions of normal distribution and variance homogeneity. Often the studies are interrupted and there are values below the limit of detection [12].

The purpose of our study was to evaluate Trzemna River water quality after wastewater effluent diversion in terms of parameters that can be obtained from State Environmental Monitoring.

Among the available statistical methods, the ones that allow for developing data based on the existing monitoring systems of surface water were proposed, considering the gaps in measurement strings, lack of normal distribution and variance homogeneity as well as utilisation in analyses of impact assessment such as before-after and before-after-control-impact research design.

\section{Materials and Methods}

\section{Study Site}

The Trzemna River is one of the most polluted lowland watercourses in Poland [17-18]. It is a left tributary of the Prosna River; the total area of its catchment is $119.2 \mathrm{~km}^{2}$ and the average inclination is 5.48\%. The headwaters of the river are located near the Czachory village at the altitude of $126.50 \mathrm{~m}$ a.s.l. and its mouth is at the ordinate $91.10 \mathrm{~m}$ a.s.1., river length is ca. $21 \mathrm{~km}$, which gives a longitudinal inclination of the watercourse of $1.73 \%$. At $5.6 \mathrm{~km}$ of the river, there is an earth dam of the Gołuchów Reservoir. Mean annual flow in the Gołuchów Reservoir cross-section is $0.37 \mathrm{~m}^{3} \cdot \mathrm{s}^{-1}$ and the reservoir area at normal water level is 51.5 ha. About 12,500 people live within the area of the catchment. The largest settlement is Gołuchów, populated by 2,300 people. Ciemna watercourse, which is the tributary of the Ołobok River, flows southeast in the same area as the Trzemna. Both watercourses clearly bifurcate in the watershed [17-20]. The analysed area can be characterised by low annual precipitation (ca. 517 $\mathrm{mm}$ ) compared to other regions of Poland and very intensive agricultural production. In 2005-14 annual consumption of nitrogenous fertilisers increased here from 65 to $90 \mathrm{~kg} \cdot \mathrm{ha}^{-1}$, and in 2011-13 it amounted to $94 \mathrm{~kg} \cdot \mathrm{ha}^{-1}$. Arable land represents $80 \%$ and forests $8.6 \%$ of the total catchment area. The catchment consists of glacial sands and tills covering the area of Wysoczyzna Kaliska,

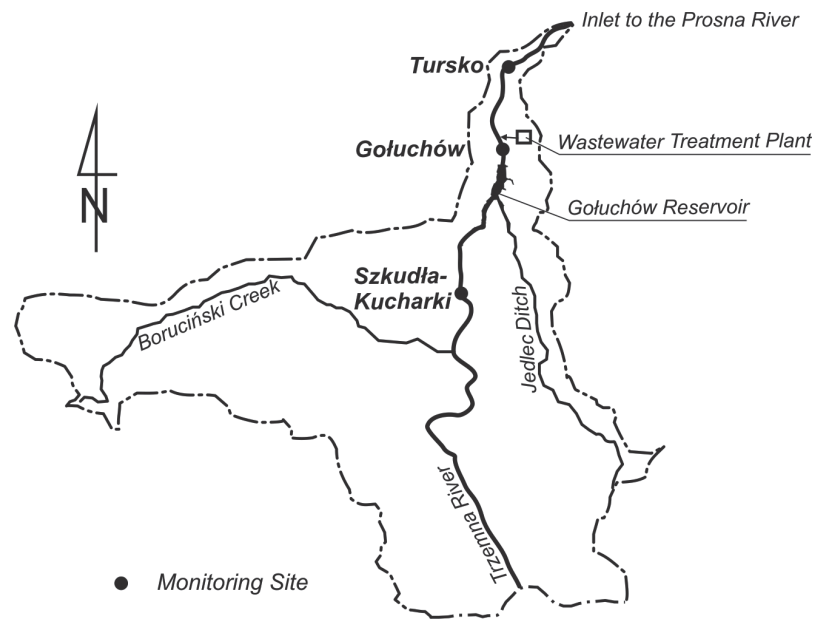

Fig. 1. The Trzemna River catchment 
and there are no significant water and wind erosion phenomena [18-20].

Although a WWTP was built in Gołuchów in 1992, the sewage system was not developed back then and wastewater was not regularly delivered to the plant. The WWTP was found to be one of the main sources of river pollution. For many years it worked ineffectively and the actual quantity of treated wastewater was only $25 \%$ of the $1,131 \mathrm{~m}^{3} \cdot \mathrm{d}^{-1}$ permissible pursuant to binding law [21]. A thorough modernisation of the WWTP was initiated in 2007. The modern treatment plant can collect $800 \mathrm{~m}^{3}$ of wastewater per day. The sewage system covers an area populated by 3,000 people and is still being developed. Since 2008, treated wastewater is discharged to the Prosna River, bypassing the Trzemna River [18].

The Trzemna is monitored for water quality at three monitoring sites (MS): MS Szkudła-Kucharki, MS Gołuchów, and MS Tursko (Fig. 1). MS SzkudłaKucharki closes a fragment of the catchment of area 82 $\mathrm{km}^{2}$, MS Gołuchów $114 \mathrm{~km}^{2}$ (area larger by $32 \mathrm{~km}^{2}$ ), and MS Tursko $118 \mathrm{~km}^{2}$ (area gain of $4 \mathrm{~km}^{2}$ ). MS Gołuchów was liquidated in 2007 due to changes in surface water monitoring principles in Poland. WWTP discharge is located between MS Gołuchów and Tursko (Fig. 1). Studies performed before treatment plant modernisation by Dąbrowska [18] in 2004-06 showed that contamination of $\mathrm{N}$ and $\mathrm{P}$ in the Trzemna River in MS Tursko significantly varied from concentration in other sites. In the case of MS Szkudła-Kucharki and MS Gołuchów, nitrates were the predominating form of nitrogen, and in Tursko ammonium and organic nitrogen. Average annual concentration of phosphates increased in MS Tursko by up to eight times compared to values measured in Gołuchów.

MS Gołuchów is located below the town, between it and MS Tursko, a gain of the catchment was only $4 \mathrm{~km}^{2}$, and $\mathrm{P}$ concentration increased three times (and $\mathrm{N}$ more than two times) - disproportionate to the gain of the catchment area (Table 1). The sole meaningful source of pollution was the discharge from a treatment plant. Forest and parks dominate within the analysed section of the catchment. It is not extensively agriculturally used and sources of pollution negligibly affect the water quality of this small area. The influence of the Gołuchów Reservoir on water quality is not significant. No major nutrient accumulation or release was observed there [18]. The slight, but first of all, constant influence of the reservoir on river water quality enabled us to conduct analyses with use of the selected BA and BACI methods.

\section{Water Quality Data}

Data from the State Environmental Monitoring database was used in the study. All available data series for the analysed area from 2005-14 were obtained from the Voivodeship Inspectorate for Environmental Protection in Poznań. Studies were performed in 2004, 2005, 2006, 2008, 2009, 2010, and 2013; $\mathrm{N}=74$ determinations were available for each examined index. Data was divided in the middle to the "pre-WED" (since January 2004 to June 2008) and "post-WED" periods (July 2008 to December 2013). According to general monitoring principles concerning measurements below the limit of determination, the value corresponding to half of the limit of detection was used in statistical analyses. Within 2005-14 it was only possible to compare physicochemical parameters, and biological hydromorphological quality elements were not measured within the whole study period.

\section{Methods}

\section{Before-After and Before-After-Control-Impact Research Designs}

The easiest way to detect changes in an aquatic environment caused by the sudden change of a factor or factors affecting the surroundings (e.g., by point sources of pollution) is the before-after design (Fig. 2). The situation where in small catchments there is data from only one monitoring point before and after an event that affects the environment is very frequent. The impact of an event on the environment is determined by comparing observations before and after using a two-sample test [22]. The weakness of this method is that the difference in the analysis is attributed to the examined activity. Observed changes can also be caused by natural temporal variations [23-24]. The study can be developed by trend analysis before and after the event [14].

To improve sensitivity of this method and exclude natural temporal variations, samples also can be taken at the control sites. This extended method is called beforeafter-control-impact (BACI) design (Fig. 2). In the case of BACI, data is collected in a control and impact zone before and after impact. The simplest example of a BACI experiment is water quality monitoring on spots upstream and downstream of the facility discharging pollutants

Table 1. Concentrations of nitrogen and phosphorous in the Trzemna River [18].

\begin{tabular}{|c|c|c|c|c|c|c|c|}
\hline \multirow[b]{2}{*}{ Year } & \multicolumn{2}{|c|}{ MS Szkudła-Kucharki } & \multicolumn{2}{|c|}{ MS Gołuchów } & \multirow{5}{*}{ 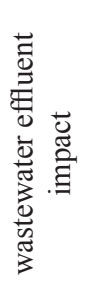 } & \multicolumn{2}{|c|}{ MS Tursko } \\
\hline & $\begin{array}{c}\text { Total P } \\
\mathrm{mg} \mathrm{P} \cdot \mathrm{dm}^{-3}\end{array}$ & $\begin{array}{c}\text { Total N } \\
\mathrm{mg} \mathrm{N} \cdot \mathrm{dm}^{-3}\end{array}$ & 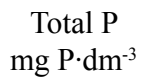 & $\begin{array}{c}\text { Total N } \\
\mathrm{mg} \mathrm{N} \cdot \mathrm{dm}^{-3}\end{array}$ & & $\begin{array}{c}\text { Total P } \\
\mathrm{mg} \mathrm{P} \cdot \mathrm{dm}^{-3}\end{array}$ & $\begin{array}{c}\text { Total N } \\
\mathrm{mg} \mathrm{N} \cdot \mathrm{dm}^{-3}\end{array}$ \\
\hline 2004 & 0.39 & 7.98 & 0.66 & 6.69 & & 2.01 & 15.56 \\
\hline 2005 & 0.42 & 9.10 & 0.61 & 10.88 & & 2.37 & 18.95 \\
\hline 2006 & 0.38 & 11.31 & 0.33 & 9.01 & & 1.51 & 13.09 \\
\hline
\end{tabular}


to a river, before and after construction of the given factory or treatment plant. Most often, the analysis

a)

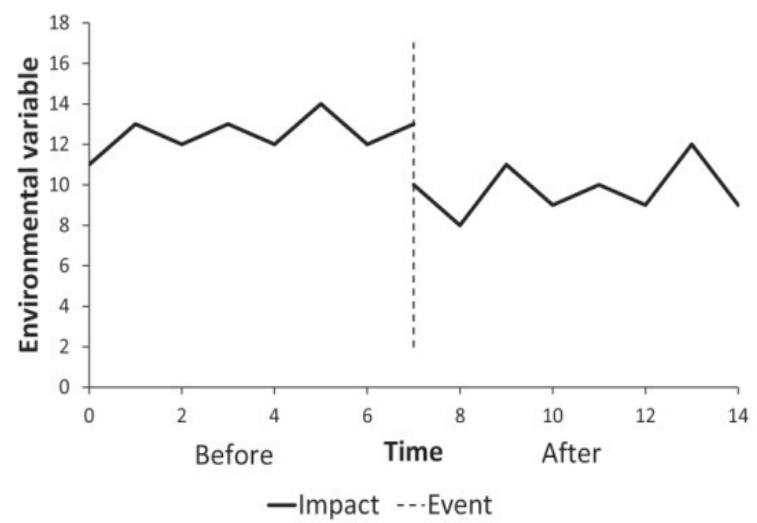

b)
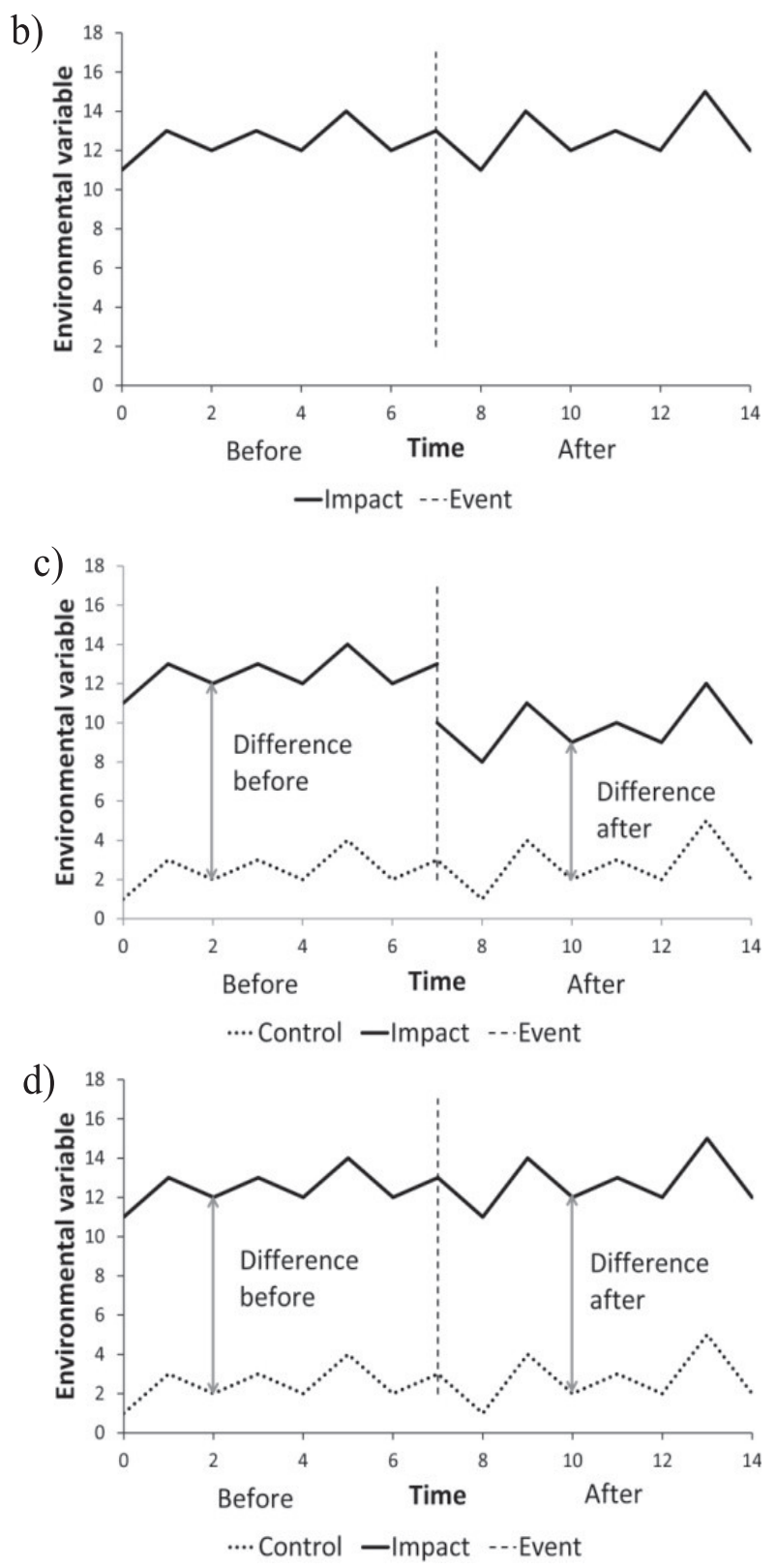

Fig. 2. Simplified data profiles for: a) BA analysis assuming impact, b) BA analysis assuming no impact, c) BACI analysis assuming impact, d) BACI analysis assuming no impact [23-24]. consists in the calculation of differences between data pairs (BACI paired) from the control and the impact sites. Then one compares the before differences against the after differences [23, 25]. To develop data in BACI analysis of variance, ANOVA or nonparametric tests are used depending on data type [14, 22-23]. Based on this method, multiple site experiments are developed along with other more complicated solutions where multivariate analysis of ecological data is used. These are known as "beyond BACI" designs [22-23, 26].

Our paper concerns the BA and BACI concept to examine the before (pre-WED) and after (post-WED) conditions of the Trzemna River (MS Tursko), as well as to compare a control (MS Szkudła-Kucharki) with the impact site (MS Tursko).

\section{Statistical Analysis}

Analyses were conducted with the use of Statistica v. 12 and XLSTAT 2015 software. Levene's test showed that data does not have homogeneous variances, thus to compare water quality differences before and after the WED period we used a nonparametric U Mann-Whitney test. The measurement of central tendency for this test is median in the case of data related to water quality outliers affecting the mean.

To identify trends we used the Mann-Kendall test - a commonly used nonparametric hydrological test. It can be applied when the gap in data string does not exceed onethird of the total record, which allows for the use of monotonic trend analysis $[12,27]$.

The verification of the hypothesis is based on MannKendall statistic $S$ [28-29]:

$$
S=\sum_{k=1}^{n-1} \sum_{j=k+1}^{n} \operatorname{sgn}\left(x_{j}-x_{k}\right)
$$

...where $x$ is the observed value in the time sequential order, $n$ is the number of observations, and $\operatorname{sgn}\left(x_{j}-x_{k}\right)$ is an indicator function:

$$
\left\{\begin{array}{c}
\operatorname{sgn}\left(x_{j}-x_{k}\right)=1 \text { if } x_{j}-x_{k}>0 \\
\operatorname{sgn}\left(x_{j}-x_{k}\right)=0 \text { if } x_{j}-x_{k}=0 \\
\operatorname{sgn}\left(x_{j}-x_{k}\right)=-1 \text { if } x_{j}-x_{k}<0
\end{array}\right.
$$

The non-parametric equivalent of the correlation coefficient used in the Mann-Kendall test is Kendall's tau. The positive value of Kendall's tau demonstrates an increase of one variable with the increase of the other. The negative value of Kendall's tau demonstrates a decrease with the increase of the other. If one of the variables is time, the positive value of Kendall's tau means a tendency to increase in time while a negative value indicates a decrease in time. The p-value is calculated to determine the statistical significance of Kendall's tau [28-29]. 
Table 2. Results of BA analysis for MS Tursko.

\begin{tabular}{|c|c|c|c|}
\hline \multirow{2}{*}{ Parameter } & $\begin{array}{l}\text { Pre-WED } \\
\text { period }\end{array}$ & $\begin{array}{l}\text { Post-WED } \\
\text { period }\end{array}$ & \multirow{2}{*}{ p-value } \\
\hline & \multicolumn{2}{|c|}{$\begin{array}{c}\text { Median } \\
\text { Mean } \pm \text { SD }\end{array}$} & \\
\hline $\mathrm{pH}$ & $\begin{array}{c}7.7 \\
-\end{array}$ & $\begin{array}{c}7.5 \\
-\end{array}$ & 0.385 \\
\hline $\begin{array}{l}\text { Dissolved Oxygen } \\
\text { DO }\left(\mathrm{mg} \mathrm{O}_{2} \cdot \mathrm{dm}^{-3}\right)\end{array}$ & $\begin{array}{c}6.6 \\
6.9 \pm 3.2\end{array}$ & $\begin{array}{c}8.1 \\
8.5 \pm 3.1\end{array}$ & $0.033^{*}$ \\
\hline $\begin{array}{c}\mathrm{BOD}_{5} \\
\left(\mathrm{mg} \mathrm{O}_{2} \cdot \mathrm{dm}^{-3}\right)\end{array}$ & $\begin{array}{c}7.0 \\
8.3 \pm 4.4\end{array}$ & $\begin{array}{c}4.0 \\
4.2 \pm 1.9\end{array}$ & $0.000^{*}$ \\
\hline $\begin{array}{l}\text { Total Nitrogen TN } \\
\quad\left(\mathrm{mg} \mathrm{N} \cdot \mathrm{dm}^{-3}\right)\end{array}$ & $\begin{array}{c}14.2 \\
15.8 \pm 3.2\end{array}$ & $\begin{array}{c}7.5 \\
11.7 \pm 9.9\end{array}$ & $0.028 *$ \\
\hline $\begin{array}{c}\text { Nitrate } \\
\left(\mathrm{mg} \mathrm{NO}_{3}^{-} \cdot \mathrm{dm}^{-3}\right) \\
\end{array}$ & $\begin{array}{c}18.2 \\
26.7 \pm 25.4\end{array}$ & $\begin{array}{c}24.1 \\
43.8 \pm 45.3 \\
\end{array}$ & 0.178 \\
\hline $\begin{array}{c}\text { Nitrite } \\
\left(\mathrm{mg} \mathrm{NO}_{2}^{-} \cdot \mathrm{dm}^{-3}\right)\end{array}$ & $\begin{array}{c}0.5 \\
1.0 \pm 1.3\end{array}$ & $\begin{array}{c}0.2 \\
0.2 \pm 0.2\end{array}$ & $0.000^{*}$ \\
\hline $\begin{array}{c}\text { Ammonium Ni- } \\
\text { trogen } \\
\left(\mathrm{mg} \mathrm{N}^{\left.-\mathrm{dm}^{-3}\right)}\right.\end{array}$ & $\begin{array}{c}4.1 \\
6.6 \pm 8.4\end{array}$ & $\begin{array}{c}0.1 \\
0.1 \pm 0.1\end{array}$ & $0.000 *$ \\
\hline $\begin{array}{c}\text { Total Kjeldahl } \\
\text { Nitrogen TKN } \\
\left(\mathrm{mg} \mathrm{N} \cdot \mathrm{dm}^{-3}\right)\end{array}$ & $\begin{array}{c}5.6 \\
9.5 \pm 9.6\end{array}$ & $\begin{array}{c}1.5 \\
1.5 \pm 0.6\end{array}$ & $0.000^{*}$ \\
\hline $\begin{array}{c}\text { Total Phosphorus } \\
\text { TP } \\
\left(\mathrm{mg} \mathrm{P} \cdot \mathrm{dm}^{-3}\right)\end{array}$ & $\begin{array}{c}1.2 \\
1.8 \pm 1.6\end{array}$ & $\begin{array}{c}0.2 \\
0.3 \pm 0.2\end{array}$ & $0.000^{*}$ \\
\hline $\begin{array}{c}\text { Phosphate } \\
\left(\mathrm{mg} \mathrm{PO}_{4}^{3-\cdot} \cdot \mathrm{dm}^{-3}\right)\end{array}$ & $\begin{array}{c}2.8 \\
4.4 \pm 4.1 \\
\end{array}$ & $\begin{array}{c}0.4 \\
0.5 \pm 0.5 \\
\end{array}$ & $0.000^{*}$ \\
\hline $\begin{array}{l}\text { Total Organic } \\
\text { Carbon TOC } \\
\left(\mathrm{mg} \mathrm{C} \cdot \mathrm{dm}^{-3}\right)\end{array}$ & $\begin{array}{c}10.7 \\
11.8 \pm 4.3\end{array}$ & $\begin{array}{c}10.1 \\
10.1 \pm 2.1\end{array}$ & 0.134 \\
\hline $\begin{array}{l}\text { Electrical Conduc- } \\
\text { tivity at } 20^{\circ} \mathrm{C} \text { EC } \\
\qquad\left(\mu \mathrm{S} \cdot \mathrm{cm}^{-1}\right)\end{array}$ & $\begin{array}{c}862.5 \\
891.8 \pm 170.6\end{array}$ & $\begin{array}{c}730.5 \\
754.7 \pm 134.3\end{array}$ & $0.000^{*}$ \\
\hline
\end{tabular}

*statistically significant difference

\section{Results and Discussion}

\section{Before-After Design}

Concentration of nutrients determined in the river in the period pre-WED is very high compared to other watercourses in this part of Europe [4-5, 8, 30-34]. For example, mean concentrations in Serafa watercourse, also affected by wastewater effluents, were as follows: TN $10.9 \mathrm{mg} \mathrm{N} \cdot \mathrm{dm}^{-3}$, TKN $5.6 \mathrm{mg} \mathrm{N} \cdot \mathrm{dm}^{-3}$, nitrate $22.0 \mathrm{mg} \mathrm{NO}{ }^{-} \cdot \mathrm{dm}^{-3}$, ammonium nitrogen $3.5 \mathrm{mg} \mathrm{N} \cdot \mathrm{dm}^{-3}$, TP $1.1 \mathrm{mg} \mathrm{P} \cdot \mathrm{dm}^{-3}$, phosphate $1.4 \mathrm{mg} \mathrm{PO}_{4}^{3-\cdot} \mathrm{dm}^{-3}, \mathrm{BOD}_{5}$ $11.7 \mathrm{mg} \mathrm{O} \cdot \mathrm{dm}^{-3}$, and DO $5.8 \mathrm{mg} \mathrm{O} \cdot \mathrm{dm}^{-3}$ [8]; in the small polluted lowland Dębina River, DO was $7.7 \mathrm{mg}$ $\mathrm{O}_{2} \cdot \mathrm{dm}^{-3}, \mathrm{BOD}_{5} 2.5 \mathrm{mg} \mathrm{O} \cdot \mathrm{dm}^{-3}$, nitrate $31.0 \mathrm{mg} \mathrm{NO}_{3}^{-}$ $\cdot \mathrm{dm}^{-3}$, and nitrite $0.3 \mathrm{mg} \mathrm{NO}_{2}^{-\cdot} \cdot \mathrm{dm}^{-3}$ [34]. A similar impact of insufficiently treated wastewater on water quality in receiving water was proven by many authors [7-9, 35-36]. Most studies present the statistically significant impact of introducing insufficiently treated wastewater on nitrate concentration in receiving waters; in case of the Trzemna there is no statistical significance for this parameter.

In the post-WED period, concentrations of most nutrient forms, $\mathrm{EC}$, and $\mathrm{BOD}_{5}$ are comparable with those analysed in the literature. The exception is high nitrate concentration. Furthermore, the concentration of nitrates and TN in the Trzemna after wastewater effluent diversion is characterised by a rising trend (Table 3 ) caused by the dynamic increase in agricultural nitrate pollution in the catchment. The aforementioned significant increase in the annual consumption of nitrogenous fertilizers seems to play an important role in the occurring process. Due to this, in 2012 the analysed area was classified as a nitratevulnerable zone by the director of the Regional Water Management Board in Poznan [37].

BA analysis in the case of 12 physicochemical parameters of the Trzemna water using the nonparametric U Mann-Whitney test showed that water quality with respect to most of the examined parameters has improved within the post-WED period (Table 2). Statistically, no significant differences were detected for nitrate, $\mathrm{pH}$, and TOC.

Analysis of trends of the remaining parameters using the Mann-Kendall test showed that within the pre-WED period, $\mathrm{pH}$, concentration of ammonium nitrogen, and TKN had a decreasing trend. Within the post-WED period in relation to $\mathrm{pH}$ and concentrations of TN and nitrate, a rising trend was observed, and in case of concentrations of TP and phosphate a decreasing trend (Table 3).

Based on the average concentrations of $\mathrm{N}$ and $\mathrm{P}$ in the Trzemna River measured in MS Tursko (Table 2) in the pre-WED $\left(15.8 \mathrm{mg} \mathrm{N} \cdot \mathrm{dm}^{-3}, 1.8 \mathrm{mg} \mathrm{P} \cdot \mathrm{dm}^{-3}\right)$ and postWED periods $\left(11.7 \mathrm{mg} \mathrm{N} \cdot \mathrm{dm}^{-3}, 0.3 \mathrm{mg} \mathrm{P} \cdot \mathrm{dm}^{-3}\right)$, we found $\mathrm{N}: \mathrm{P}=9: 1$ in the pre-WED period, and 39:1 in the postWED period. The N:P ratio decides which of the nutrients stimulate algae development. When the N:P ratio $<10$ the development of algae is limited by nitrogen, when it is $10-20$ a cumulative limitation by both these elements is perceived, and when N:P $>20$ the amount of algae is limited by phosphorus [38-39]. Wastewater effluent diversion not only caused improvement of water quality, but also the element limiting algae development in the river from nitrogen to phosphorus.

\section{Before-After-Control-Impact Design}

The BACI could be performed for six physicochemical parameters (Table 4), because only in this case were measurements taken in pairs within the same period before (pre-WED) and after for the control (MS SzkudłaKucharki) and the impact site (MS Tursko). The nonparametric U Mann-Whitney test was used to analyse statistical significance of differences among the tested parameters in the control and impact sites, before and after WED. It was shown that there are no statistically significant differences for DO and nitrate concentrations, and differences in the remaining parameters were statistically 
Table 3. Results of trend analysis in water quality in MS Tursko.

\begin{tabular}{|c|c|c|c|c|c|c|c|c|}
\hline \multirow[b]{2}{*}{ Parameter } & \multicolumn{4}{|c|}{$\begin{array}{l}\text { Pre-WED } \\
\text { period }\end{array}$} & \multicolumn{4}{|c|}{$\begin{array}{l}\text { Post-WED } \\
\text { period }\end{array}$} \\
\hline & $\begin{array}{l}\text { Mann- } \\
\text { Kendall } \\
\text { statistic }\end{array}$ & $\begin{array}{l}\text { Kendall's } \\
\text { tau }\end{array}$ & $\mathrm{p}$-value & $\begin{array}{l}\text { Trend } \\
\text { nature }\end{array}$ & $\begin{array}{l}\text { Mann- } \\
\text { Kendall } \\
\text { statistic }\end{array}$ & $\begin{array}{l}\text { Kendall's } \\
\text { tau }\end{array}$ & $\mathrm{p}$-value & $\begin{array}{l}\text { Trend } \\
\text { nature }\end{array}$ \\
\hline $\mathrm{pH}$ & -203 & -0.272 & $0.018 *$ & decreasing & 205 & 0.378 & $0.002 *$ & increasing \\
\hline $\begin{array}{l}\text { Dissolved Oxygen DO (mg } \\
\left.\qquad \mathrm{O}_{2} \cdot \mathrm{dm}^{-3}\right)\end{array}$ & -52 & -0.067 & 0.552 & no trend & 117 & 0.209 & 0.086 & no trend \\
\hline $\begin{array}{c}\mathrm{BOD}_{5} \\
\left(\mathrm{mg} \mathrm{O}_{2} \cdot \mathrm{dm}^{-3}\right)\end{array}$ & 65 & 0.084 & 0.465 & no trend & 97 & 0.173 & 0.155 & no trend \\
\hline $\begin{array}{l}\text { Total Nitrogen TN } \\
\quad\left(\mathrm{mg} \mathrm{N}^{\left.-\mathrm{dm}^{-3}\right)}\right.\end{array}$ & -74 & -0.095 & 0.398 & no trend & 177 & 0.316 & $0.008^{*}$ & increasing \\
\hline $\begin{array}{c}\text { Nitrate } \\
\left(\mathrm{mg} \mathrm{NO}_{3}^{-} \cdot \mathrm{dm}^{-3}\right)\end{array}$ & 92 & 0.118 & 0.291 & no trend & 191 & 0.341 & $0.005^{*}$ & increasing \\
\hline $\begin{array}{c}\text { Nitrite } \\
\left(\mathrm{mg} \mathrm{NO}_{2}^{-\cdot} \cdot \mathrm{dm}^{-3}\right)\end{array}$ & 126 & 0.162 & 0.146 & no trend & 70 & 0.125 & 0.306 & no trend \\
\hline $\begin{array}{l}\text { Ammonium Nitrogen } \\
\left(\mathrm{mg} \mathrm{N} \cdot \mathrm{dm}^{-3}\right)\end{array}$ & -189 & -0.242 & $0.028 *$ & decreasing & 74 & 0.132 & 0.279 & no trend \\
\hline 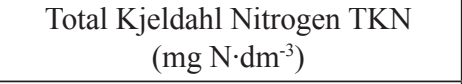 & -179 & -0.230 & $0.038^{*}$ & decreasing & 5 & 0.009 & 0.953 & no trend \\
\hline 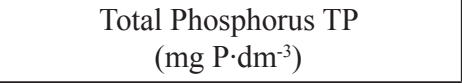 & -97 & -0.124 & 0.263 & no trend & -172 & -0.307 & $0.011^{*}$ & decreasing \\
\hline $\begin{array}{c}\text { Phosphate } \\
\left(\mathrm{mg} \mathrm{PO}_{4}^{3-\cdot} \cdot \mathrm{dm}^{-3}\right)\end{array}$ & -114 & -0.146 & 0.189 & no trend & -198 & -0.353 & $0.003^{*}$ & decreasing \\
\hline $\begin{array}{l}\text { Total Organic Carbon TOC } \\
\left(\mathrm{mg} \mathrm{C} \cdot \mathrm{dm}^{-3}\right)\end{array}$ & 111 & 0.143 & 0.200 & no trend & -9 & -0.016 & 0.906 & no trend \\
\hline $\begin{array}{l}\text { Electrical Conductivity at } 20^{\circ} \mathrm{C} \text { EC } \\
\left(\mu \mathrm{S} \cdot \mathrm{cm}^{-1}\right)\end{array}$ & -116 & -0.149 & 0.180 & no trend & 26 & 0.046 & 0.711 & no trend \\
\hline
\end{tabular}

*statistically significant difference

Table 4. Results of BACI analysis: control site MS Szkudła-Kucharki vs. impact site MS Tursko.

\begin{tabular}{|c|c|c|c|c|c|}
\hline \multirow[t]{2}{*}{ Parameter } & $\begin{array}{l}\text { Szkudła-Kucharki } \\
\text { Control } \\
\text { Pre-WED } \\
\text { period }\end{array}$ & $\begin{array}{l}\text { Szkudła-Kucharki } \\
\text { Control } \\
\text { Post-WED } \\
\text { period }\end{array}$ & $\begin{array}{l}\text { Tursko } \\
\text { Impact } \\
\text { Pre-WED } \\
\text { period }\end{array}$ & $\begin{array}{c}\text { Tursko } \\
\text { Impact } \\
\text { Post-WED } \\
\text { period }\end{array}$ & \multirow[t]{2}{*}{$\begin{array}{c}\text { Differences } \\
\text { comparison } \\
\text { (p-value) }\end{array}$} \\
\hline & \multicolumn{2}{|c|}{$\begin{array}{c}\text { Median } \\
\text { Mean } \pm \text { SD }\end{array}$} & \multicolumn{2}{|c|}{$\begin{array}{c}\text { Median } \\
\text { Mean } \pm \text { SD }\end{array}$} & \\
\hline $\begin{array}{l}\text { Dissolved Oxygen DO } \\
\quad\left(\mathrm{mg} \mathrm{O}_{2} \cdot \mathrm{dm}^{-3}\right)\end{array}$ & $\begin{array}{c}9.0 \\
8.3 \pm 3.7\end{array}$ & $\begin{array}{c}8.9 \\
8.8 \pm 2.4\end{array}$ & $\begin{array}{c}6.6 \\
6.9 \pm 3.2\end{array}$ & $\begin{array}{c}8.1 \\
8.5 \pm 3.1\end{array}$ & 0.235 \\
\hline $\begin{array}{l}\text { Total Nitrogen TN } \\
\quad\left(\mathrm{mg} \mathrm{N} \cdot \mathrm{dm}^{-3}\right)\end{array}$ & $\begin{array}{c}8.1 \\
10.5 \pm 7.6\end{array}$ & $\begin{array}{c}12.1 \\
14.4 \pm 8.8\end{array}$ & $\begin{array}{c}14.2 \\
15.8 \pm 3.2\end{array}$ & $\begin{array}{c}7.5 \\
11.7 \pm 9.9\end{array}$ & $0.000^{*}$ \\
\hline $\begin{array}{c}\text { Nitrate } \\
\left(\mathrm{mg} \mathrm{NO}_{3}^{-} \cdot \mathrm{dm}^{-3}\right)\end{array}$ & $\begin{array}{c}26.6 \\
39.7 \pm 35.6\end{array}$ & $\begin{array}{c}43.9 \\
57.7 \pm 40.3\end{array}$ & $\begin{array}{c}18.2 \\
26.7 \pm 25.4\end{array}$ & $\begin{array}{c}24.1 \\
43.8 \pm 45.3\end{array}$ & 0.065 \\
\hline 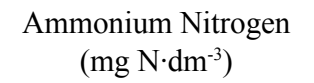 & $\begin{array}{c}0.2 \\
0.3 \pm 0.4\end{array}$ & $\begin{array}{c}0.1 \\
0.2 \pm 0.2\end{array}$ & $\begin{array}{c}4.1 \\
6.6 \pm 8.4\end{array}$ & $\begin{array}{c}0.1 \\
0.1 \pm 0.1\end{array}$ & $0.000 *$ \\
\hline $\begin{array}{c}\text { Total Kjeldahl Nitrogen } \\
\text { TKN } \\
\left(\mathrm{mg} \mathrm{N} \cdot \mathrm{dm}^{-3}\right)\end{array}$ & $\begin{array}{c}1.7 \\
1.8 \pm 0.7\end{array}$ & $\begin{array}{c}1.3 \\
1.3 \pm 0.6\end{array}$ & $\begin{array}{c}5.6 \\
9.5 \pm 9.6\end{array}$ & $\begin{array}{c}1.5 \\
1.5 \pm 0.6\end{array}$ & $0.000^{*}$ \\
\hline 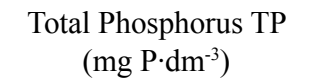 & $\begin{array}{c}0.3 \\
0.4 \pm 0.2\end{array}$ & $\begin{array}{c}0.3 \\
0.3 \pm 0.2\end{array}$ & $\begin{array}{c}1.2 \\
1.8 \pm 1.6\end{array}$ & $\begin{array}{c}0.2 \\
0.3 \pm 0.2\end{array}$ & $0.000^{*}$ \\
\hline
\end{tabular}

*statistically significant difference 
significant. The WWTP in Gołuchów was not a significant source of nitrate pollution. Main nitrate pollution sources are situated in the area of the catchment controlled by MS Szkudła-Kucharki, where cultivated fields are located. Below that point there are mainly non-agricultural areas [17-18]. Thus, the concentration of nitrates in the Trzemna decreases along its course, and in MS Szkudła-Kucharki it is higher than that in MS Tursko in both the pre-WED and post-WED periods (Table 4). Similar relations were also found by Dąbrowska [18] in her earlier studies conducted before the modernisation of the WWTP.

Differences between BA and BACI analysis were found for DO, and in BACI analysis no impact of WED was detected on the change of this parameter. BACI design eliminates the impact of climatic and other factors not related to discharge of wastewater, thus the results of this method are found to be more reliable. The BACI analysis usually provides less probability of detecting changes compared to BA. In their works, Korman and Higgins [40] noted a $10-15 \%$ lower probability of detecting a population change in the case of the BACI method unless the degree of covariation in survival rates between the control and treatment stocks was very strong. In the case of the Trzemna water quality tests, the difference between the highest $\mathrm{p}$-values for BACI and BA methods were detected for DO; it is also worth noting that in the BA method p-value for DO was the closest to 0.05 of all parameters whose differences were statistically significant.

\section{Summary and Conclusions}

BA analysis showed that as a result of WWTP modernisation in Gołuchów and wastewater effluent diversion, Trzemna River water quality has improved with respect to phosphorus compounds, EC, ammonium nitrogen, $\mathrm{TKN}, \mathrm{TN}$, and $\mathrm{BOD}_{5}$ The change did not affect concentrations of nitrate, TOC, and $\mathrm{pH}$. Due to the necessity to compare data pairs measured within the same time at the control and the impact sites, BACI analysis could be performed for six out of 12 parameters. It has also demonstrated a significant impact of WED on the concentration of TN, TKN, ammonium nitrogen, and TP in the Trzemna River. Differences between these two methods were noticeable for DO. In the BA analysis, changes of concentration of DO were statistically significant while in BACI they were not. The BA and BACI analyses can be successfully used to detect positive changes in river water quality (i.e., for the control of restoration measures) and to support integrated catchment management. BACI requires more data, which in some cases of its gathering from the State Environmental Monitoring nets will reduce the number of parameters for which comparison can be performed. Due to the nature of data, nonparametric tests should be performed.

The performed studies show that despite significant improvement of water quality in the river resulting from improved wastewater management, high concentrations of nitrates related to agricultural pollution are a current problem in the case of the Trzemna River catchment.

\section{References}

1. DĄBROWSKAJ., LEJCUŚK., KUŚNIERZM., CZAMARA A., KAMIŃSKA J., LEJCUŚ I. Phosphate dynamics in the drinking water catchment area of the Dobromierz Reservoir. Desalination and Water Treatment 57 (53), 25600, 2016.

2. KALAJI H.M., SYTAR O., BRESTIC M., SAMBORSKA I.A., CETNER M.D., CARPENTIER C. Risk assessment of urban lake water quality based on in-situ cyanobacterial and total chlorophyll- $a$ monitoring. Pol. J. Environ. Stud. 25 (2), 655, 2016.

3. ROBINSON C.S., TETREAULT G.R., MCMASTER M.E., SERVOS M.R. Impacts of a tertiary treated municipal wastewater effluent on the carbon and nitrogen stable isotope signatures of two darter species (Etheostoma blennioides and E. caeruleum) in a small receiving environment. Ecol. Indic. 60, 594, 2016.

4. KIEDRZYŃSKA E., KIEDRZYŃSKI M., URBANIAK M., MAGNUSZEWSKI A., SKŁODOWSKI M., WYRWICKA A., ZALEWSKI M. Point sources of nutrient pollution in the lowland river catchment in the context of the Baltic Sea eutrophication. Ecol. Eng. 70, 337, 2014.

5. SPÄNHOFF B., BISHOF R., BÖHME A., LORENZ S. Assessing the impact of effluents from a modern wastewater treatment plant on breakdown of coarse particulate organic matter and benthic macroinvertebrates in a lowland river. Water Air Soil Poll. 180, 119, 2007.

6. GONG D., GAO X., NTAKIRUTIMANA T., GUO J., LI $\mathrm{K}$. Water quality status along the Liangtan River and control planning alternatives for pollution reduction. Pol. J. Environ. Stud. 22 (4), 1061, 2013.

7. MOMBA M.N.B., OSODE A.N., SIBEWU M. The impact of inadequate wastewater treatment on the receiving water bodies - case study: Buffalo City and Nkokonbe municipalities of the Eastern Cape Province. Water SA 32 (5), 687, 2006.

8. KANOWNIK W., POLICHT-LATAWIEC A. Changeability of oxygen and biogenic indices in waters flowing through areas under various anthropopressures. Pol. J. Environ. Stud. 24 (4), 1633, 2015.

9. NEVEROWA-DZIOPAK E., CIERLIKOWSKA P. Impact of wastewater treatment plant modernization on trophic state of recipient. Ochr. Sr. 36 (2), 53, 2014.

10. JANIK G., OLSZEWSKA B., PŁYWACZYK L., ŁYCZKO W., ALBERT M., NOWICKA E. Applicability of geostatistical tools and fractal theory for the estimation of the effect of a river on water relations in adjacent area. River Research and Applications 32 (6), 1342, 2015.

11. KÖSE E., TOKATLI C., ÇIÇEK A. Monitoring stream water quality: a statistical evaluation. Pol. J. Environ. Stud. 23 (5), 1637, 2014.

12. HIRSCH R.M., SLACK J.R., SMITH R.A. Techniques of trend analysis for monthly water quality data. Water Resour. Res. 18 (1), 107, 1982.

13. GREEN R.H. Sampling Design and Statistical Methods for Environmental Biologists, John Wiley and Sons Inc, USA, 1979.

14. HUGHES A., QUINN J. Before and after integrated catchment management in a headwater catchment: changes in water quality. Environ. Manage. 54 (6), 1288, 2014. 
15. MUTSERT K., COWAN J.H. JR. A before-after-controlimpact analysis of the effects of a Mississippi River freshwater diversion on estuarine Nekton in Louisiana, USA. Estuar. Coasts 35 (5), 1237, 2012.

16. HONG S.K., LEE J.A., IHM B.S., FARINA A., SON Y., EUN-SHIK K., CHOE J.C. (Eds.). Ecological Issues in a Changing World: Status, Response and Strategy. Kluwer Academic Publishers, The Netherlands, 2004.

17. DABROWSKA J. Influence of natural, anthropogenic and technological factors on water quality in the Gołuchów Reservoir. Wydawnictwo Uniwersytetu Przyrodniczego we Wrocławiu, Wrocław 2008.

18. DĄBROWSKA J. Evaluation of the content of nitrogen and phosphorus compounds in the waters of Trzemna River. Infrastructure and Ecology of Rural Areas 7, 57, 2008.

19. Central Statistical Office of Poland, Local Data Bank, www. stat.gov.pl, Data as of 25-th February 2016

20. CZARNECKA H. Atlas of hydrographic division of Poland. IMGW, Warszawa 2005.

21. Report on the state of the environment in Wielkopolska 2001. Voivodeship Inspectorate for Environmental Protection in Poznań, Poznań 2002.

22. PETRAITIS P. Designing experiments that control for spatial and temporal variation. Methodology paper series of the $4^{\text {th }}$ International Conference on ILTER in East Asia and Pacific Region, Ulaanbaatar-Hatgal, Mongolia, 2001.

23. SMITH E.P. BACI design. Encyclopedia of Environmetrics Vol.1, John Wiley \& Sons, Ltd, Chichester, 2002.

24. STEWART-OATEN A., MURDOCH W.W. Environmental impact assessment: "pseudoreplication" in time? Ecology 67 (4), 929, 1986

25. OSENBERG C.W., SCHMITT R.J., HOLBROOK J.S., ABU-SABA K.E., FLEGAL A.R. Detection of environmental impacts: natural variability, effect size, and power analysis. Ecol. Appl. 4 (1), 16, 1994.

26. SMITH E.P., ORVOS D.R., CAIRNS J. Impact assessment using the Before-After-Control-Impact (BACI) Model: Concerns and Comments. Can. J. Fish. Aquat. Sci. 50 (3), 627, 1993.

27. HELSEL, D.R., HIRSCH R.M. Statistical methods in water resources techniques of water Resources investigations, Book 4, Chapter A3. U.S. Geological Survey, 2002.

28. RONG Y. Practical Environmental Statistics and Data Analysis (Advanced Topics in Environmental Science), ILM Publications, Saint Albans, Hertfordshire, 2011.
29. MAKSYMIUK A., FURMAŃCZYK K., IGNAR S., KRUPA J., OKRUSZKO T. Analysis of climatic and hydrologic parameters variability in the Biebrza River basin. Scientific Review: Engineering and Environmental Sciences 41, 59, 2008.

30. JASKUŁA J., SOJKA M., WICHER-DYSARZ J. Analysis of trends changes in physicochemical state of the Główna River. Inżynieria Ekologiczna 44, 2015.

31. KOWALIK T., KANOWNIK W., BOGDAŁ A., POLICHTLATAWIEC A. Effect of change of small upland catchment use on surface water quality course. Rocz. Ochr. Sr. 16, 223, 2014.

32. ORZEPOWSKI W., PARUCH A.M., PULIKOWSKI K., KOWALCZYK T., POKŁADEK R. Quantitative and qualitative assessment of agricultural water resources under variable climatic conditions of Silesian Lowlands (Southwest Poland). Agr. Water Manage. 138, 45, 2014.

33. SKORBIŁOWICZ M., OFMAN P. Seasonal changes of nitrogen and phosphorus concentration in Supraśl River. J. Ecol. Eng. 15 (1), 26, 2014.

34. SOJKA M., MURAT BŁAŻEJEWSKA S. Physico-chemical and hydromorphological state of a small lowland river. Rocz. Ochr. Sr. 11, 727, 2009.

35. POLICHT-LATAWIEC A., KANOWNIK W., ŁUKASIK D. Effect of point source pollution on the San River water quality. Infrastructure and Ecology of Rural Areas. 1 (IV), 253, 2013.

36. LEWANDOWSKA-ROBAK M., GÓRSKI Ł., KOWALKOWSKI T., DĄBKOWSKA-NASKRĘT H., MIESIKOWSKA I. The influence of treated sewage discharged from wastewater treatment plant in Tuchola on water quality of Kicz stream. Inżynieria i Ochrona Środowiska, 14 (3), 209, 2011.

37. Regulation of the Director of the Regional Water Management Board in Poznań, 12.07.2012. The Official Journal of the Greater Poland Voivodeship, No 3143, 12.07.2012, 2012.

38. SOLOVEY T. Evaluation of potential eutrophication in running waters of the central Vistula catchment basin. WodaŚrodowisko-Obszary Wiejskie 8 (1), 323, 2008.

39. JI Z.G. Hydrodynamics and water quality: modeling rivers, lakes, and estuaries. John Wiley \& Sons, Inc., Hoboken, New Jersey, 2007.

40. KORMAN J., HIGGINS P.S. Utility of escapement time series data for monitoring the response of salmon populations to habitat alteration. Can. J. Fish. Aquat. Sci. 54 (9), 2058, 1997. 